\title{
In Memoriam: Susan Berry Brill de Ramirez (1955-2018)
}

James T. LaPlant, SPUR Editor-in-Chief

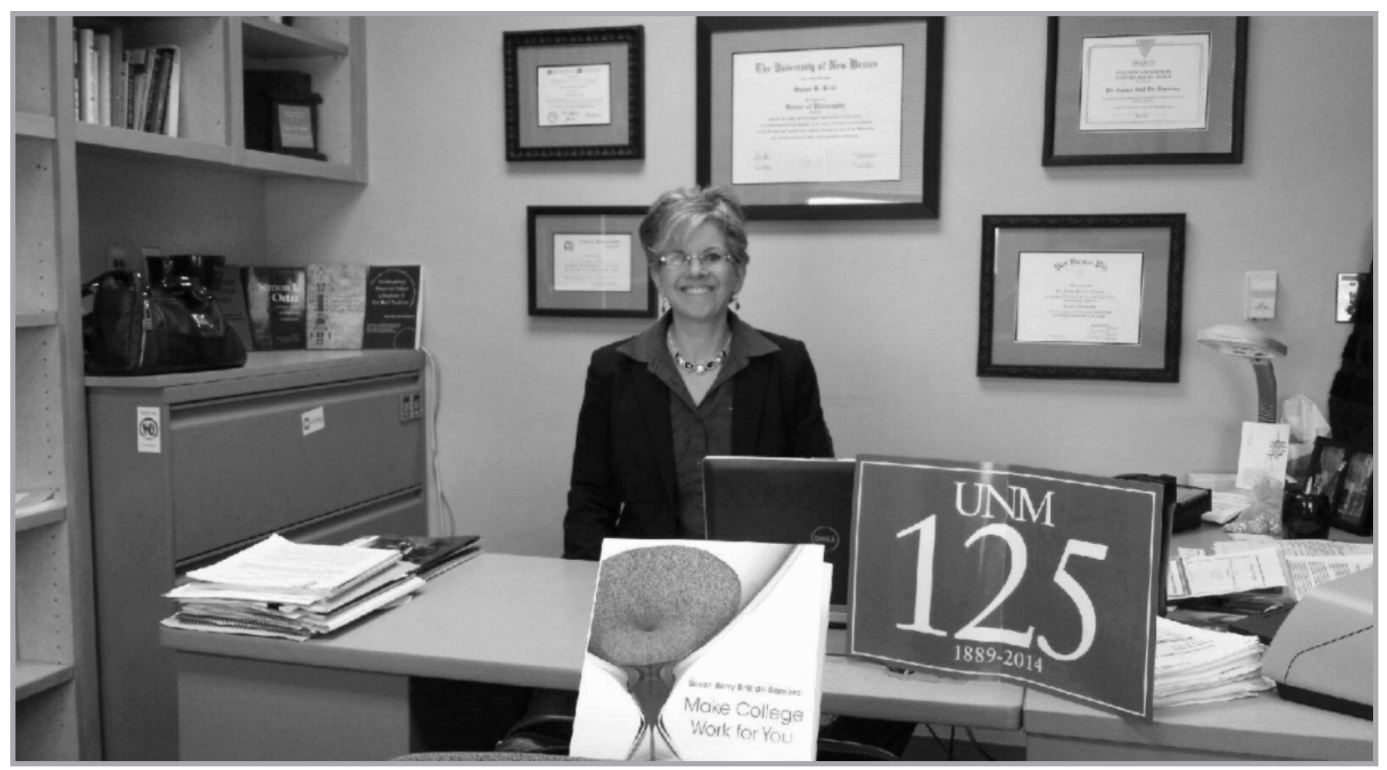

Susan Berry Brill de Ramirez in her office in 2014. Photo courtesy of the University of New Mexico Alumni Association.

\section{doi: $10.18833 /$ spur/3/1/9}

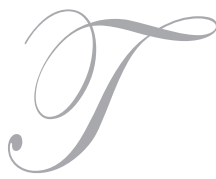

he Council on Undergraduate Research and the SPUR Editorial Board are saddened to note the passing of Susan Berry Brill de Ramirez. Susan earned her BA in English from the University of WisconsinMadison, her MA in English from the University of Chicago, her MBA in management and human resources from the University of Wisconsin, and her PhD in English from the University of New Mexico. She taught at Bradley University in the Department of English from 1991 to 2018 where she was a gifted teacher and a distinguished scholar of Indigenous literary studies. In addition to receiving a number of teaching and research awards, Susan held the endowed Caterpillar Professor of English. Her students won competitive Expo Awards at Bradley University for their distinguished research.
Susan was a CUR Councilor in the Arts and Humanities Division. Susan also served as the CUR journal book review editor from spring 2014 to summer 2018. Her service crossed over from the last volumes of CUR Quarterly through the inaugural volume of Scholarship and Practice of Undergraduate Research. Susan's passion and enthusiasm for undergraduate research were evident with each book review that she penned. Her mentoring of undergraduate research was also on display through the students at Bradley University who wrote book reviews with her. Susan was a valuable voice on the Editorial Board as CUR's flagship journal was redesigned and launched. I am a better mentor of undergraduate research and a stronger editor of this journal because of the opportunity to work alongside Susan and benefit from her good humor, wisdom, and passion for undergraduate research. We will miss her, and her memory will be honored through the pages of this journal. 


\section{AUTHOR SUBMISSION GUIDELINES}

\section{Scope}

As an international, cross-disciplinary, peer-reviewed publication of the Council on Undergraduate Research, Scholarship and Practice of Undergraduate Research (SPUR) publishes scholarly work that examines effective practice and novel approaches, explores pedagogical models, and highlights the results of assessment of undergraduate research, scholarship, and creative activities in all disciplines and at all types of higher education institutions in the United States and abroad.

Prospective authors do not have to be members of CUR to submit their work to the journal for peer review and consideration for publication. Faculty and students who wish to publish the products or results of their specific undergraduate research endeavors are encouraged to consider other disciplinary or student-focused journals.

\section{Editorial Policies}

All articles are peer-reviewed. Editorial judgment regarding publication of manuscripts rests with the editors. Concerns about editorial policies and decisions should be addressed to the editors.

\section{Types of Submissions}

There are several types of manuscripts accepted by SPUR for review. Articles selected for publication may be interdisciplinary or centered in a specific discipline and generally fall into one of three categories: theory, practice, or assessment. Submission types include the following:

1. Articles of general interest to the SPUR readership. Articles that are within the scope of SPUR may be submitted for review at any time. Articles originating from international institutions or programs are welcome at any time for review and/or may be invited by the International Perspectives editors. Authors are encouraged to discuss their submission with one of the editors listed on the inside cover of the journal to ensure relevance of content and scope.

2. Invited articles connected to a theme issue.

Issue themes are announced through a call for prospectus (CFP) process approximately one year before intended publication date. Selected articles are invited for submission and peer review by a specified deadline.

3. Invited vignettes relevant to a theme issue. Shorter pieces, called vignettes, are also invited through the CFP process.

4. Reviews of recent books of interest to the SPUR readership.

Book reviews are invited by the book review editor. Suggestions for books to review that have been published in the preceding 12 months may be sent to the book review editor for consideration.

\section{Undergraduate Research Highlights}

Each issue of SPUR includes a summary of recent research copublished by faculty and undergraduate students. Highlights must have been published within the past six months in peer-reviewed book chapters, scholarly journals, or proceedings, as appropriate to the discipline.

\section{Checklist for submission of article manuscripts:}

- Copy must be in MS Word or compatible format, Times New Roman font, 12-point, double-spaced, 1 -inch margins, and one space after periods.
- Length: 2000-3500 words is the typical length of an article (exclusive of references), but longer or shorter articles may be appropriate for certain topics.

- Keywords for indexing: up to 6.

- Abstract: maximum 125 words.

- Proper Citations. Refer to the Chicago Manual of Style citation guidelines-author-date style (http://www. chicagomanualofstyle. org/tools_citationguide.html).

- Figures and tables must be numbered and include captions (max. 8 figures and tables).

- Photographs must be in grayscale and at least $300 \mathrm{dpi}$.

- Personal information for the authors includes:

- Full name and institution for all authors;

- Institutional title, postal address, and email address for the corresponding author; and

- Biographical sketch for each author (75-word limit each).

- Authors wishing to supplement their manuscript with supporting information must secure prior permission from the editors.

\section{Special instructions for Vignettes, Book Reviews,} and Undergraduate Research Highlights:

\section{Vignettes and Book Reviews}

- Copy as above.

- Vignette length: maximum 400 words. Book review length: maximum 650 words.

- Keywords: up to 3.

- No section headings or figures.

- Minimal references (Chicago Manual of Style as above) may be included.

- Authors' full name and institutional affiliations; mailing and email addresses for corresponding author.

- No abstract or author biosketches are needed.

\section{Undergraduate Research Highlights}

- Title of the article/book chapter and full journal citation for articles (inclusive pages; Chicago Manual of Style).

- A brief description (maximum 75 words) of the research and its significance. Copy guidelines as above.

- Title and department or program affiliation of the faculty member

- A brief (maximum 75 words per coauthor) description of the student coauthor(s) including the year of study in which the student(s) undertook the work, the opportunity through which the work was done (independent study project, summer project, REU program, senior thesis project, etc.), and the student's current status (graduate school, employed, still enrolled, etc.).

- The source of funding for the work.

\section{Submit Online}

Once all items on the appropriate checklist are completed, visit https:// spur.msubmit.net and complete the online submission process.

\section{For general questions regarding SPUR, contact:}

James T. LaPlant

SPUR Editor-in-Chief

Dean of Humanities and Social Sciences

Valdosta State University

jlaplant@valdosta.edu 